University of Chicago Law School

Chicago Unbound

Journal Articles

Faculty Scholarship

1936

\title{
Some Fundamental Differences in Real Property Ideas of the Civil Law and the Common Law Systems
}

Max Rheinstein

Follow this and additional works at: https://chicagounbound.uchicago.edu/journal_articles

Part of the Law Commons

\section{Recommended Citation}

Max Rheinstein, "Some Fundamental Differences in Real Property Ideas of the Civil Law and the Common Law Systems," 3 University of Chicago Law Review 624 (1936).

This Article is brought to you for free and open access by the Faculty Scholarship at Chicago Unbound. It has been accepted for inclusion in Journal Articles by an authorized administrator of Chicago Unbound. For more information, please contact unbound@law.uchicago.edu. 


\title{
COMMENT
}

\section{SOME FUNDAMENTAL DIFFERENCES IN REAL PROP- ERTY IDEAS OF THE "CIVIL LAW" AND THE COMMON LAW SYSTEMS*}

\author{
MAX RHEINSTEIN $\dagger$
}

\begin{abstract}
$\Lambda^{\mathrm{CO}}$ COMPARISON of the real property law ideas and approaches of the civil law and the common law encounters the initial diffculty that there is no longer such a thing as "Civil Law." The laws of those countries which are more or less based on the Roman law are widely different from one another at the present time. ${ }^{x}$ Yet there are certain common features, which I shall attempt to emphasize. Where it is necessary to go into more detail, attention shall be paid principally to the law of Germany, not only because it is the system with which I happen to be most familiar, but particularly because it is contained in one of the most recent and most elaborate of the great European codes. ${ }^{2}$
\end{abstract}

* This paper was read in December, I935, before the Round Table on Property and Status at the meeting of the American Law School Association in New Orleans. The references to code provisions and literature were added for its publication here; it has not been changed or enlarged, however. It is intended as an expression of a few ideas in the form of a sketch, with the hope that the author may obtain knowledge of individual reactions for use in future work.

$\dagger$ Assistant Professor of Law, holder of Max Pam Professorship, University of Chicago Law School.

I In the discussion following the presentation of this paper, Dean Pound observed that in the common law jurisdictions as well, modern legislation and other factors have brought about considerable differences in the laws actually in force in the various jurisdictions. However, the "Common Law" is still felt to be a single system: it is still taught as such in English and especially American universities, and even "restated." In Europe the consciousness of a common background has been lost through the nationalization of the laws of the various countries. What is taught in the universities is French, German, Italian, or some other national law. Roman common law finds no more than historical interest. No one would even think of restating the no longer existing "Civil Law," the last remains of which lost actual interest when the Roman common law was superseded in Germany by the new Civil Code. Cf. also, in this respect, Rheinstein, Comparative Law and Conflict of Laws in Germany, 2 Univ. Chi. L. Rev. 232 (I935).

2 German Civil Code (Bürgerliches Gesetzbuch, usually abbreviated B. G. B.) of August I8, 1896. Of a more recent date are the civil codes of Switzerland (December I0, I907) (which has been almost literally adopted by the Turkish Republic), Brazil, Liechtenstein, Guatemala, Siam, Iran, and the various Soviet Republics. All these codes were considerably influenced by the German code. 
The existence of these codes marks the first great difference between common law and civil law. In all the civil law countries, codification meant a fresh start, a great housecleaning, where antiquated rules and institutions were weeded out. New consistent rules were worked out, unhampered by ideas developed in and adapted to the needs of past ages. ${ }^{3}$ In the field of the land laws this re-shaping was perhaps more radical than in other fields. ${ }^{4}$

This process of destruction and re-building was principally guided by two policies: (I) the desire to suppress the political power of the landed aristocracy; and (2) the idea of economic liberalism: the common good would be served best by the greatest possible marketability of the land, the result expected being that every piece of land would always be in the ablest and fittest hands.

Two principal legal means were used for giving effect to these policies:

I. Restraints on alienation were curtailed or even almost entirely suppressed.

II. A system of conveyancing was established which was intended not only to simplify the formalities of land transactions but also to guarantee the utmost security for bona fide purchasers and mortgagees.

I

The first means was not only aimed at the landed classes but also consciously used for the purpose of giving greater security to land transactions, since it became apparent at an early date that without a radical simplification of the substantive law of real property no conveyancing reform would be able to achieve the desired end.

Restraints on alienation existed in the civil law countries, although never to the same extent as in England. They were partly traditional, based upon old forms of community property of the family or the village; partly, their foundation lay, as in England, in feudal ideas and institutions. ${ }^{5}$ But these were almost entirely swept away in the reforms of the nineteenth century.

In the common law, there exists another form of restraint on aliena-

3 On these reforms, $c f$. "The Progress of Continental Law in the Nineteenth Century," by various authors, Ir Continental Legal History Series $25 \mathrm{I}$ fi. (I9I8).

"The standard work on the nineteenth century continental reforms of the land laws is Justus Wilhelm Fledemann, Die Fortschritte des Zivilrechts im rg. Jahrhundert ( 2 vols. IgI8, I930).

$s$ For detailed information, see Rudolf Huebner, History of Germanic Private Law, 4 Continental Legal History Series 3 Ig ff., 395 ff., 758 ff. (Igr8); Jean Brissaud, History of French Private Law, 3 Continental Legal History Series $30 \mathrm{ff} ., 426$ ff. (Igra). 
tions, i.e., one which is created by a legal transaction of an individual who wishes to fix the legal fate of a certain piece of property for a more or less distant future. The technical means by which such a desire can be fulfilled is the future interest. The civil law has developed a rather different institution, the fideicommissary substitutions. By means of this device a person fixes the future fate not of any individual object but only of his estate as a whole. Furthermore, and in contrast to the common law, this can only be done by an instrument of a testamentary nature. By using the so-called fideicommissum universale a person could provide that upon his death the heir of his heir ${ }^{6}$ should be obliged to hand over the entire estate to some other person, the fideicommissary. ${ }^{7}$ Local developments, especially in Germany, subsequently changed this institution to the socalled "Nacherbfolge," (reversionary heirship) under which a testator may provide that upon his death his entire estate should pass to A, and after A's death, or upon some other event, immediately to $B$, and eventually, upon some further event, even to a third person. He may not make such a provision, however, with respect to a particular piece of land, Blackacre or Whiteacre. ${ }^{8}$

If $\mathrm{T}$ dies leaving his estate to $\mathrm{A}$ for life and then to $\mathrm{B}$, the former, on principle, becomes the free and unrestricted owner of the entire estate. He has the power and, on principle, the right to alienate everything.9 On the other hand, he is bound to hand over to B "the estate," i.e., its economic value. Whenever he sells an object belonging to the estate, the proceeds or whatever he buys with them take its place. ${ }^{\text {xo }}$ Hence it follows that he is not allowed to make gifts, except with the consent of the "secondary heir" or heirs, as the case may be. Any gift made out of the estate without such consent is invalid. ${ }^{\text {II }}$

"Throughout this paper, the word "heir" is not used in its technical common law meaning, but as a translation of the civil law term "heres" (French "héritier," German "Erbe," Italian "erede," Spanish "heredero") meaning that person to whom the decedent's estate passes as an entirety immediately upon death; of. Rheinstein, European Methods for the Liquidation of the Debts of Deceased Persons, 20 Iowa L. J. 43I (I935).

${ }_{7}$ Cf., e.g., D. 35.2.95. pr., 36.I.27.r6, 36.r.57.x.

${ }^{8}$ See Germ. Civ. Code $\$ \S 2100-46$; Swiss Civ. Code arts. 488-92; Austrian Civ. Code $\S \S 604$ et seq. ( $f f .2$ Ehrenzweig, System des österreichischen allgemeinen Privatrechts, II, 432 (6th ed. I924)).

${ }^{9}$ Cf. Germ. Civ. Code $\$ 2$ II2; Swiss Civ. Code art. 49I.

so Germ. Civ. Code $\S 2$ IrI.

II This is expressly provided in Germ. Civ. Code $\S 2 \pi_{3}$, $2 \mathrm{~d}$ par. The gift is invalid "in so far as it would frustrate or impair the rights of the reversionary heir." The prohibition does not apply to gifts which are made in consideration of a moral duty or of a duty of social etiquette. 
On principle, he should be allowed to sell freely any piece of land belonging to the estate. However, land is regarded as such an important asset that modern German law provides for an exception. Any sale of land made by a primary heir out of the estate without the consent of the secondary heir or heirs is invalid in so far as it impairs the rights of the latter..$^{12}$ On the other hand, the primary heir is possessor and owner of the land and registered as such in the Land Register. In order to protect third parties, however, the Land Registry is required to enter on the Land Register, on its own motion, a notice that the person entered as owner is merely a primary heir. ${ }^{{ }^{3}}$ Unless this notice has been entered, bona fide purchasers and mortgagees will acquire a good title from the primary heir. ${ }^{14}$

A secondary heir may be appointed upon a certain or an uncertain event. It may be certain or uncertain that the position of the primary heir will be terminated. A husband, for instance, may appoint his wife his heir until her remarriage, or until her death, and from then on B or, if $B$ should be dead, C. Thus, legal situations may be created very similar to the future interests and expectancies under the common law.

However, the instrument creating such interests must be a will. No "future interest" can be created by an inter vivos transaction. Yet, there exists a legal transaction which, though in testamentary form, strikingly resembles an inter vivos transaction, the "pacts of inheritance." ${ }_{\text {IS }}$ A person may make a will in the form of an agreement. $A$, in an agreement with $B$, may appoint $\mathrm{B}$ or $\mathrm{C}$ as his heir. This is more than a contract by which $\mathrm{A}$ would undertake to make such and such a will. The agreement is the will, which is irrevocable without the other party's consent. It is possible and usual for both parties to such "pacts of inheritance" to make dispositions as to their respective estates. Such reciprocal "pacts of inheritance" may be combined in one document with an agreement in which future or present spouses fix their respective rights in each other's property. Such "pacts of matrimony and inheritance" fulfill the functions of an English marriage settlement. Yet, while an English marriage settlement will refer to Blackacre or Whiteacre, the German document refers to the respective estates as entireties, and only indirectly will it affect the individual pieces of land belonging to the parties at the time of their deaths.

12 Germ. Civ. Code § 2II3, Ist par.

${ }_{3}$ Land Registry Regulation $\$ \mathbf{5 2}$. ${ }^{4}$ Germ. Civ. Code $\S 2 \mathrm{II} 3,3^{\mathrm{d}}$ par.

${ }_{25}$ Erbvertrag. Germ. Civ. Code $\$ \S 2279-2302$; Swiss Civ. Code arts. 494-7; Austrian Civ. Code (permitted only as between husband and wife) $\$ \$ 602$, I 249 et seq. As to its history, see Huebner, op. cit. supra note 5 , at 746 . 
The law must take care, moreover, of a person's desire to exempt a particular thing from the general fate of his estate. One may desire his estate to go to A; Blackacre, however, to $\mathrm{B}$. He may effect his purpose by means of a legacy. However, there is a difference between a common law devise and the modern civil law legacy. If under the common law a man devises Blackacre to B, title passes to B immediately upon the testator's death. In Germany title passes to the heir; all $B$ acquires is a claim against the heir, which can be defeated by the heir's conveying the land to a third party. Then $B$ has nothing more than a claim for damages against the heir. ${ }^{16}$

By means of a special type of legacy, a testator may provide that the heir shall convey Blackacre to B, and that, after B's death, B's heir shall convey it to C. By this device, the legatum fideicommissarium ("Nachvermächtnis"), ${ }^{17}$ nothing more can be created than claims in personam against the person charged with their execution. Yet, modern German law has developed a means by which the "future legatee" may protect his claim against defeat by adverse dispositions of the primary legatee. $\mathrm{He}$ may enter upon the land register a warning by which the public is notified of his future claim. The present owner is not prevented thereby from transferring the title to third persons, but he can only give them a title which is defeasible upon the maturity of the claim of the "future legatee." 18 This protection comes in its effect very near to an Anglo-American future interest.

The rule that future interests can be created only with respect to an estate as a whole, is a consequence of that peculiar attitude of the civil law which finds its theoretical expression in the distinction made there between law of property and law of succession. While the former looks to single objects and their transfer inter vivos, the latter regulates succession upon death which is always conceived of as a so-called universal succes-

${ }^{26} \mathrm{Germ}$. Civ. Code $\$ \S$ I939, 2I47, 2I74; Swiss Civ. Code arts. 48I, 484-6; Austrian Civ. Code $\$ \S 535,647$ et seq. The Iegacy has also been embodied in the French Code (art. Ior 4 et seq.), and in the codes of those numerous other countries which follow the French pattern (cf., e.g., the Italian Civil Code arts. 760, 827, 862 et seq.; Roumanian Civil Code arts. 887, 899 et seq.; Spanish Civil Code art. 858 et seq.). Under Roman law, it was not only possible to charge the heir with a duty to hand over a certain object to the legatee (legatum per damnotionem), but also, just as under common law, to devise a certain thing in such a way that the legatee acquired the title immediately on the testator's death (legatum per vindicationem).

${ }_{17}$ Roman law: of. D. 32.39. pr., 35.r.36.I, C. 6. 53.2. Modern laws: Germ. Civ. Code $\S$ 2I9I; Swiss Civ. Code art. 488, 3d par.; Austrian Civ. Code $\S 652$; for the laws of the French system, see p. 630 infra.

${ }^{18}$ Germ. Civ. Code $\$ 883$. 
sion, i.e., succession to a person's entire estate. ${ }^{19}$ In the classical common law, universal succession applied to personal property only, i.e., to that part of a deceased person's property which was taken care of in England by the ecclesiastical courts, which based their rules not on common law but on civil law ideas. While these courts developed the rule that a deceased man's personal estate passed to his personal representative as an entirety, the common law courts treated each piece of land as a separate unit. $^{20}$ They did so, for example, with respect to venue, the conflict of laws, or the dower and curtesy rights of a surviving spouse. In the civil law, on the other hand, those rights which might be regarded as analogous to dower and curtesy refer only to the estate as a whole, i.e., to those objects which happen to belong to the estate at the moment of the precedent spouse's death. To express it in common law terms: The rights of the surviving spouse can be defeated by an alienation inter vivos. It is merely one consequence of this general policy that future interests can be created only with respect to an estate as a whole, and only by testamentary transactions.

However, an exception persisted during a certain period. In the late sixteenth and seventeenth centuries, the same period during which inventive English lawyers responded to the desires of the English landed aristocracy by the invention of the "family settlement," continental lawyers developed for the same purpose the so-called "fideicommissa familiarum." ${ }_{22}$ This institution could be used to settle, by a testamentary or inter vivos "act of settlement," a piece of land with its fixtures and appurtenances (usually a large manor) so as to make it inalienable, indivisible, unmortgageable, exempt from execution, and subject to inheritance by primogeniture or some other system of entailed succession. Usually, care was taken to provide for all possible eventualities and contingencies,

19 As to this principle of "universal succession," $f f$. Buckland, Textbook of Roman Law 206 et seq. (2d ed. 1932); Sohm, Institutes of Roman Law $406 \mathrm{ff}$. (Ledlie's transl. r892); see also Rheinstein, op. cit. supra note 6.

${ }^{20}$ In this respect the common law kept in line with the general ideas of the Germanic laws; cf. 2 Pollock \& Maitland, History of English Law 253 ff. (1895); Huebner, op. cit. supra note 5, at $699 \mathrm{ff}$.

${ }^{2 x} C f .7$ Holdsworth, History of English Law II2 (I926); Pollock, Land Laws, pt. III (3d ed. 1896$)$.

22 As to their history, of. Huebner, op. cit. supra note 5, at 3ro ff., $76 \mathrm{I}$ fi. A comparative survey of the systems of these fideicommissa as they were developed in the various countries of Europe will be found in an article by Kuebler and Beutner, 3 Rechtsvergleichendes Handwörterbuch 342-68 (193I), and in Otto v. Gierke's article in 4 Handwörterbuch der Staatswissenschaften ro4 (3d ed. I909). 
so that there were rights not only analogous to reversions but also to vested and contingent remainders and even to powers of appointment. The institution was worked out by ingeniously combining Roman law with feudal and Germanic ideas which had survived the "reception."

Its use was, naturally, limited to the wealthy landed classes, i.e., the aristocracy. In some countries, e.g., in Bavaria, it was even formally reserved to the members of the nobility.

This device by which an individual manor or another piece of land could be inalienably settled upon the members of the settlor's family, was swept away in France by the Revolution. ${ }^{24}$ It was looked upon, properly, as one of the basic foundations of the power of the nobility. In order to prevent its resurrection under disguise, the French Civil Code forbade even the "universal fideicommiss" and the "fideicommissary legacy." ${ }_{25} \mathrm{On}$ principle-there are a few exceptions ${ }^{26}$ - no property can be left in France otherwise than in free, unrestricted ownership. ${ }^{27}$ Not only the fear of aristocratic power, but also the belief that any bindings of the land were an economic evil, were among the basic dogmas of the French Revolution. ${ }^{28}$ Many other countries followed the French example; not all, however, with the same radicalism.

${ }^{23}$ The Roman law basis was the so-called "fideicommissum quod familiae relinquitur," a fideicommissum in the sense as explained on p. 626 supra, with the peculiar feature that each successive fideicommissary was bound to leave the estate to a member of the family of the tes-

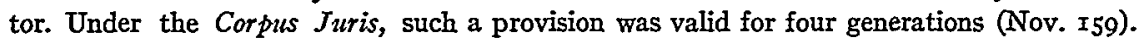
It was fused with the feudal law institution of "succession ex pacto et providentia maiorum" and the practice of entails, as it was especially developed in the Spanish institution of "majorado."

${ }^{24}$ Law of November 14, 1792.

${ }^{25}$ French Civ. Code art. 896: "Substitutions are prohibited. Every disposition by which a donee, a testamentary heir, or a legatee is charged with preserving [the estate] and to hand it over to a third person, is void, even as to the donee, the testamentary heir, or the legatee."

${ }^{26}$ See id., art. 897 which, combined with arts. 1048-79, permits certain dispositions in favor of the grandchildren of a donor or testator, or of the children of his brothers and sisters; $c f$. also p. 632 infra, as to the usufruct.

${ }^{27}$ For details of the French law, see 5 Planiol et Ripert (et Trasbot), Traité pratique de droit civil français $29 \mathrm{I}$ ff., 852 ff. (I933); shorter, 3 Colin et Capitant, Cours élémentaire de droit civil français 944 fif. (I9I6); Josserand, Cours de droit civil positif français 95I (r930); 3 Planiol, Traité elémentaire de droit civil 942 ff. (Irth ed. 1932). The courts to a certain extent admit dispositions by which an estate or a particular thing is left to $A$ under a condition subsequent, and to $B$ under the same condition working as condition precedent. Thus $T$ may leave his estate to $A$, and in case of A's dying without children, to B. A's.power to dispose of the estate can be in no way affected, however, by such a disposition. In case of the happening of the condition, $B$ will obtain nothing more than what has been left by A. A further limitation is that $B$ must have been alive or conceived at the moment of T's death.

${ }^{28}$ Cf. Montesquieu, De l'esprit des lois, v. 9 (I798); see also Aron, 25 Nouvelle revue historique de droit 468,586 (rgor). 
The German Civil Code of 1896 expressly admitted the "fideicommissa universalia" (Nacherbfolge), ${ }^{29}$ subject only to a rule against perpetuities, which is similar to the English rule, though less refined. ${ }^{30}$ The legatum fideicommissarium creating obligations with respect to specific property also remains under the code. ${ }^{3 \mathbf{3}}$

The "fideicommissum familiarum," on the other hand, was left outside the scope of the German code. It was left to the states to retain or abolish this aristocratic institution. ${ }^{32}$ In spite of numerous attacks on political and economic grounds, it was left intact in all the states until the Revolution of I9I9, which initiated extensive detailed legislation for the enfranchisement of the settled lands, ${ }^{33}$ whereby the rights of the first, and sometimes even of the second remainderman were carefully preserved. Hence, at the present moment, there are still many settled lands in Germany which, however, are bound to disappear within two generations at the latest. Perhaps family corporations may develop as substitutes. ${ }^{34}$

On the other hand, the National-Socialist régime has created a new

${ }^{29}$ Cf. p. 626 supra.

${ }^{30}$ Sec. 2rog: "The appointment of a reversionary heir (or legatee) becomes inoperative after the lapse of thirty years since the testator's death, unless the condition for the reversionary succession has happened within such period. The appointment remains operative, however, even after the lapse of thirty years, $(x)$ if the reversionary heir has been appointed under the condition of a certain event happening with reference to the person of the primary heir or the reversionary heir, provided the person with reference to whom the event is to happen was living at the time of the testator's death; (2) if a brother or sister of the primary or a reversionary heir has been appointed as reversionary heir. If the primary or reversionary heir with reference to whom the condition is to occur is a juristic person, the period of thirty years will not be enlarged."

$C f$. also the following provisions of the Austrian Civil Code:

"§ 6II. The number of reversionary heirs is not limited, provided they are all contemporaries of the testator; thus there may be three, four, or even more reversionary heirs.

"\$ 612. If the reversionary heirs are not contemporaries of the testator but born after the time when he made his will, no disposition as to moneys or any movables is valid beyond the second degree, and no disposition as to land is valid beyond the first degree." This provision means that one unborn reversionary heir may be appointed as to land, and two as to movables. See Rappaport, 2 Klang's Kommentar zum allgemeinen bürgerlichen Gesetzbuch, pt. I, p. 236 (1935).

Under the Swiss Code, no more than one reversionary heir may be appointed (art. 488 , 2d par.).

${ }^{3 x} C f$. p. 628 supra.

${ }^{32}$ Introductory Law to the Civil Code of Aug. I8, I896, art. 59, R. G. Bl. 1896, 604.

33 The principle was laid down in art. 155 of the Weimer Constitution of August II, I9r9; as to the details, see Kuebler and Beutner, op. cit. supra note 22; also Martin Wolff, 3 Enneccerus, Kipp, and Wolff, Lehrbuch des bürgerlichen Rechts 325 ff. (gth ed. I932).

34 Thus, for instance, the former Royal House of Saxony has set up a limited company under the name of "Haus Wettin, Ltd." 
form of settled lands, settled not by the will and private act of any individual but by the will of the state. By law of September $29,1933,35$ all middle-sized peasants' farms have been rendered inalienable and indivisible. Their owner can dispose of them neither inter vivos nor by will. Upon his death, they pass undivided to the youngest, or in certain parts of the country, to the eldest son. ${ }^{36}$

Thus, the National Socialist régime has returned to the idea that a man's land does not belong to his estate, that his personalty goes a separate way, and that land is subject to particular rights, to inalienable future interests.

Another method of fixing the fate of a particular object as such, and not only as a part of an estate, has been retained in all civil law countries. Everywhere a piece of land can be made the subject-matter of a usufruct for life. ${ }^{37}$ This interest in almost all important respects resembles the common law estate for life. By transaction inter vivos or testamentary, the owner may create a usufruct for a certain person and then, of course, dispose of the fraction of the right of ownership which is retained by him. This interest in many ways resembles a reversion. Neither the right of the usufructuary, however, nor the "reversion" is regarded as an "estate." The usufruct is looked upon as a "servitude," a combination of extensive easements and profits in the land of another. The "reversion" is not a future interest but simply that surplus of the rights incident to ownership which are not vested in the usufructuary and not incompatible with the latter's rights.

Thus usufruct and, in Germany and some other countries, the fideicommissary substitutions are still available for fulfilling a person's desire to provide, within limits, for the future fate of his property. Yet it seems that they are not extensively used beyond settling an estate first to the surviving spouse and then to the children of a testator. Of course, as long as statistics are lacking, such a statement cannot be based on more than subjective impressions, founded partly on personal experience, and partly on the dearth of decisions and lack of interest in the subject shown in legal literature. Although the present law of Germany affords quite a variety of means for "settling" property, I think that it can safely be said

35 R. G. Bl. 1933, I, 685.

${ }^{36}$ See Kaden, The Peasant Inheritance Law in Germany, 20 Towa L. Rev. 350 (1935).

${ }_{37}$ Cf., e.g., Germ. Civ. Code $\S$ rozo et seq.; Austrian Civ. Code $\S 509$ et seq; Swiss Civ. Code art. 745 et seq.; French Civ. Code art. 578 et seq.; Ital. Civ. Code art. 477 et seq.; Span. Civ. Code art. 467 et seq. For a comparative survey of the various modern systems of usufruct, see Rheinstein, 5 Rechtsvergleichendes Handwörterbuch 43I (I935). 
that the only extensive use made of them is for providing for a surviving spouse, who will usually be appointed the other spouse's primary heir, with the children or other relatives as secondary heirs. Provisions as to more distant events and eventualities seem to be rare. Nothing more than guessing is possible as to the causes of this difference from the customs of Anglo-American countries. One reason may be the greater rareness of large fortunes; it may also be that impulses associated with economic individualism and limits on feudal power have affected common practices; another reason may be the great consciousness of the continental nations of the instability of expectations, of the futility of provisions for the future. Nations which have gone through the experiences of succeeding wars, revolutions, and inflations, are less convinced of the permanency of present conditions than nations which for centuries have not seen an invading enemy and whose chief experiences in instability are the periodic crises of the capitalist system.

II

The policy against restraints on alienation is, as already mentioned, not only directed against an undue growth of the economic power of the landed classes, but is also directed toward facilitating the transferability of the land.

Another means to the same end is the comparative simplicity of the system of "rights in rem," especially the absence of "equities." 38 The task of research to which a purchaser or mortgagee is put is greatly lightened by the comparative simplicity of transactions, and particularly by the absence of rights of other persons "constructive notice" of which may be fatal.

Simplicity of the substantive law of real property is also indispensable for the proper functioning of the most effective device developed for securing the stability of land transactions: $3^{39}$ the land register system, ${ }^{40}$ which, however, has been adopted in only a few civil law countries, viz., in Ger-

${ }^{38}$ As to the importance of this point and the underlying policies, of. Rheinstein, review of Pierre Lepaulle, "Traite théorique et pratique des trusts," 43 Yale L. J. I049 (I934).

39 The necessity of a radical simplification of the substantive law of rights in land was recognized and carried out in the English reform legislation of I924 $_{2}$ and I926. $_{9}$

to For a comparative survey, see Schollmeyer and E. Heymann, 5 Handwörterbuch der Staatswissenschaften 335 (4th ed. I923), and Percy Bordwell, Land Transfer, 9 Soc. Sci. Ency. I27 (1933), with further references. Also Planiol, Traité élémentaire, nos. 2637-43, and Predari, 3 Rechtsvergleichendes Handwörterbuch I86 (I93r). On the German system of land registration, see especially Martin Wolf, op. cit. supra note 33, at 77 fi.; shorter, Strecker, 3 Handwörterbuch der Rechtswissenschaft 26 (1928). 
many, Austria, Switzerland, and the Scandinavian countries.4x In these countries registration of title is compulsory. A record is kept for every piece of land, and no transaction can validly be made without registration. France and the many countries following the French system have only registration of deeds developed on similar lines as registration of deeds in this country, though resulting in a greater protection of purchasers because of the greater simplicity of the substantive law..$^{42}$

Even the best system of registration of deeds leaves room for a considerable amount of insecurity. Its most serious defect is that it leaves it to the reader of the records to draw his own legal conclusions, which may or may not be right, and which will be less conclusive the more complicated the substantive law.

In a system of registration of titles, on the other hand, the record reveals and largely controls the actual legal situations. The register will tell immediately in whom title is vested, who is a mortgagee, and what the priorities are. Such a system imposes a high responsibility upon the staff of officials, who must necessarily be learned in the law. ${ }^{43}$

That the introduction of a system of compulsory registration of title is no easy task is shown by the experiences of France, England, and the United States. In France, its introduction has been advocated for almost a century. It has been prevented by the high costs which would be caused by the necessity of an almost complete remaking of the topographical land survey. ${ }^{44}$ In England, compulsory land registration was confessedly prevented by the conveyancing branch of the legal profession. A strong government, as it existed in Germany, is necessary to overcome such difficulties. It may be more than a mere accident that the radical reform of the English law of real property by Lord Birkenhead's Acts was achieved during the post-war period when bureaucracy was unusually strong in England.

Whether or not compulsory registration of title, in the long run, amounts to a saving or a greater expense for the community when compared with a different system is a problem which should attract further detailed research. It certainly does away completely with the necessity of

4I As to its history, see Huebner, op. cit. supra note 5, at $218 \mathrm{ff}$., 24I ff.; Martin Wolff, $o p$. cit. supra note 33 , at $73 \mathrm{ff}$.

$\$ 2$ On the French system of registration of deeds, see 4 Planiol et Ripert (et Picard), op. cit. supra note 27, at 604 ff., and, shorter, Planiol, Traité élémentaire, nos. 2603 et seq. (I932).

13 Thus in Germany, for instance, the keeping of the land register is entrusted to the county courts.

\$4 See Planiol, Traité élémentaire, no. 2635 (I932), with further references. 
title insurance because of the great security and stability it affords for transactions in land, an object regarded in the civil law countries as the most important end of the rules of the law of real property. This policy has been carried out most consistently in Germany. The law of real property has been so radically simplified that almost no other rights can exist in land than are possible in chattels. Future interests in land are just as restricted as they were with respect to chattels in the classical common law. The outspoken end of the German codifiers was to assimilate land transactions as far as possible to transactions in chattels or in stocks. They have so well succeeded that almost the only criticism uttered against the real property provisions of the Code is that they facilitate land transactions too much, that they induce the peasants to part too easily with or to mortgage their land, and that they involve too great a temptation to speculate in land. Whether or not such criticisms are justified is an open question. 